\title{
Model Pemanfaatan Bangunan Tradisional Jawa Sebagai Salah Satu Objek Wisata Budaya (Kasus di Kampung Kauman Yogyakarta)
}

\section{Muhammad Chawari}

Keywords: cultural resource management; settlement; kingdom; utilization; conservation; heritage

\section{How to Cite:}

Chawari, M. (2004). Model Pemanfaatan Bangunan Tradisional Jawa Sebagai Salah Satu Objek Wisata Budaya (Kasus di Kampung Kauman Yogyakarta). Berkala Arkeologi, 24(1), 112-128. https:// doi.org/10.30883/jba.v24i1.899

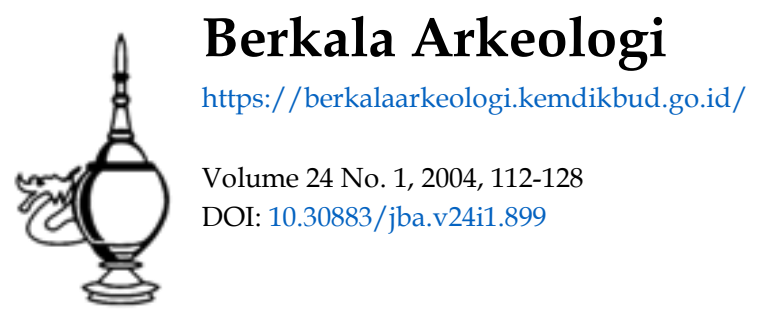

\section{cc) (i) (5)}

This work is licensed under a Creative Commons Attribution-NonCommercial-ShareAlike 4.0 International License. 


\title{
MODEL PEMANFAATAN BANGUNAN TRADISIONAL JAWA SEBAGAI SALAH SATU OBJEK WISATA BUDAYA Kasus di Kampung Kauman Yogyakarta
}

\author{
Muhammad Chawari
}

$\mathbf{L}$ atar Belakang Sejarah

Nama "Kauman" berarti tempat berdiamnya sekelompok ahli agama, di mana kampung tersebut berkaitan erat dengan keberadaan Kraton Kasultanan Yogyakarta. Kraton ini berdiri sekitar tahun 1755, berpatokan terjadinya perjanjian Giyanti yang membagi Kerajaan Mataram menjadi dua, yaitu Kasultanan Yogyakarta dan Kasunan Surakarta. Sementara itu, berdirinya Kampung Kauman tidak jauh berbeda waktunya dengan pendirian Kraton Yogyakarta tersebut, sebab Masjid Besar yang terletak di Kampung Kauman didirikan pada tahun 1773 (Chawari, 1989: 81). Dengan demikian keberadaan kampung ini tentunya tidak berbeda jauh dengan berdirinya Masjid Besar tersebut. Dengan keberadaan masjid, pihak kraton mengangkat seorang Penghulu yang tugasnya antara lain mengelola masjid, di samping tugas-tugas lain yang berhubungan dengan kraton. Penghulu kraton tersebut berada dalam struktur organisasi Kawedanan Pengulon. Kawedanan Pengulon merupakan struktur organisasi yang terdiri atas Penghulu dan seluruh aparat di bawahnya yang bertugas mengurus masjid secara operasional, yaitu Ketib, Modin, Berjama'ah, dan Merbot. Penghulu dan seluruh perangkat di bawahnya tersebut berdiam di sekitar masjid yang masuk dalam wilayah Kampung Kauman. Penghulu sebagai kepala Kawedanan Pengulon bertugas di Masjid Besar, sedangkan para Ketib selain menjadi khotib di Masjid Besar juga bertugas di masing-masing langgarnya yang terletak di samping tempat tinggalnya di dalam Kampung Kauman Yogyakarta.

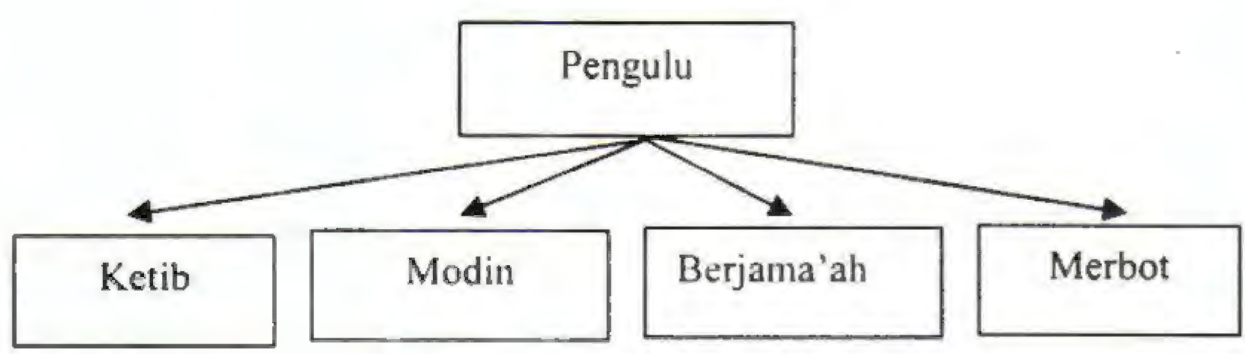




\section{B}

atasan Wilayah Amatan

Kampung Kauman terletak di wilayah Kelurahan Ngupasan, Kecamatan Gondomanan, Kotamadia Yogyakarta, Prop. D.I. Yogyakarta. Secara astronomis kampung ini terletak antara $110^{\circ} 21^{\prime} 32,4^{\prime \prime}-110^{\circ} 21^{\prime} 48,8^{\prime \prime} \mathrm{BT}$ dan $7^{\circ} 48^{\prime}$ $5,25^{\prime \prime}-7^{\circ} 48^{\prime} 18,36^{\prime \prime}$ LS.

Batas-batasnya adalah:

1. Sebelah utara merupakan Jalan KHA. Dahlan.

2. Sebelah barat merupakan Jalan Nyai Ahmad Dahlan.

3. Sebelah selatan berbatasan dengan Kecamatan Kraton yang berupa tembok keliling kraton.

4. Sebelah timur merupakan Jalan Pekapalan dan Jalan Trikora.

\section{KOTA YOGYAKARTA}
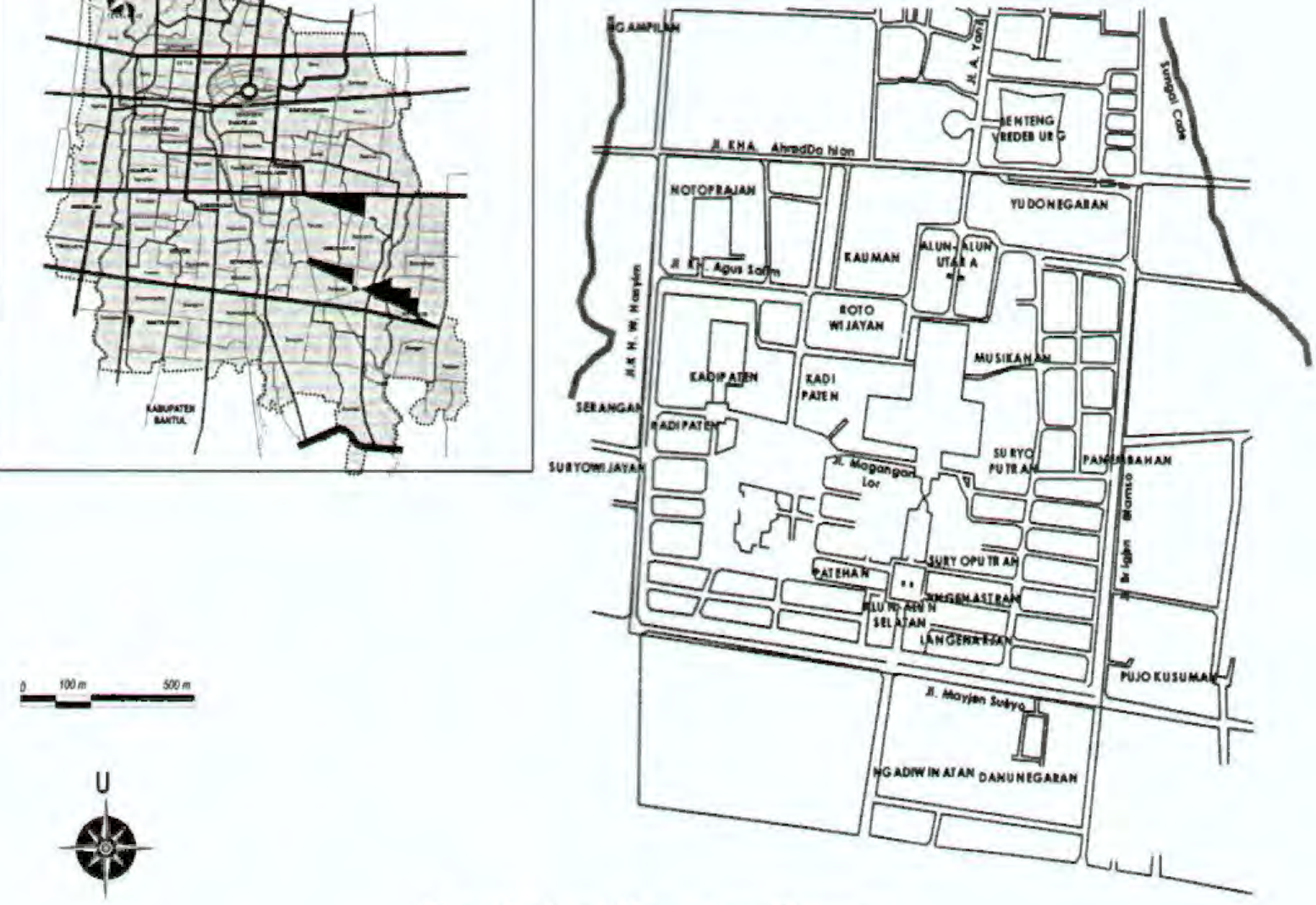

Peta Lokasi Kawasan Kauman

Sumber: Dinas Kebudayaan dan Pariwisata DIY dengan perubahan 
Mengenai uraian yang berkaitan dengan bangunan rumah tradisional Jawa yang ada di Kauman, dapat dibedakan menjadi 3, yaitu:

1. Bangunan rumah Kawedanan Pengulon. Sesuai dengan jenjang kepangkatannya, seorang Penghulu diberi nDalem Pengulon sebagai Kantor Kawedanan Pengulon dan sekaligus sebagai rumah dinas. nDalem Pengulon terletak di sebelah utara Masjid Besar, di bagian depan terdapat halaman yang cukup luas. Keduanya (ndalem dan halaman) dikelilingi beteng atau tembok dengan ketinggian sekitar 3 meter. Rumah Penghulu tersebut mempunyai ciri seperti

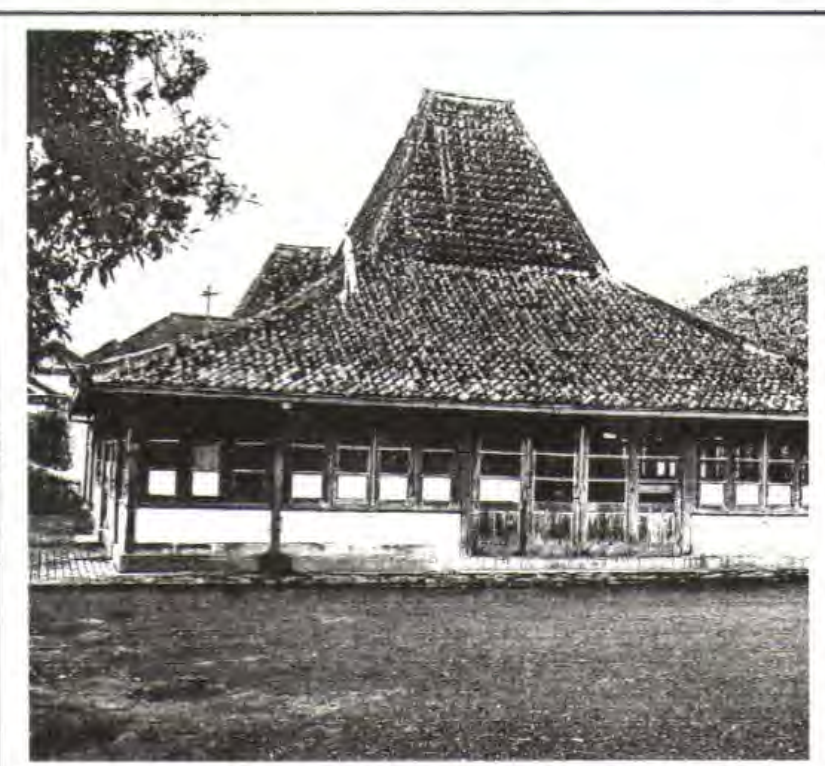

Kawedanan Pengulon. rumah tradisional Jawa yang terdiri atas pendopo, pringgitan, dalem (terdiri atas "senthong" kiwo, tengah, dan tengen), gadri, dan gandok (kiwo, tengah, dan tengah) (Chawari, 1999: 128 129). Rumah tersebut sampai sekarang masih difungsikan sebagai Kantor Kawedanan Pengulon.

2. Bangunan rumah Ketib. Ketib merupakan pejabat kraton yang jenjangnya di bawah Penghulu. Rumah Ketib bentuknya sama dengan rumah Penghulu, yang membedakan adalah tidak dilengkapi dengan tembok keliling. Di Kauman terdapat 9 buah Ketib yang langsung dikepalai oleh Penghulu, yaitu: Ketib Anom (Tibanom), Ketib Tengah, Ketib Amin (Tibamin), Ketib Wetan (Tibetan), Ketib Lor (Tibelor), Ketib Sememi, Ketib Cendono, Ketib Imam (Tibimam), dan Ketib Kulon (Darban, 2000: 11). Selain itu terdapat 2 buah Ketib yang lain yaitu: Ketib Miri dan Ketib Arum (Tibarum). Dengan demikian jumlah seluruh Ketib ada 11 yang tempat tinggalnya menyebar di seluruh Kauman.

a. Ketib Anom (Tibanom), Rumah Ketib Anom bentuknya sangat sederhana. Unsur-unsur bangunannya terdiri atas dalem, gandok, dan gadri (?), serta serta tanpa adanya pendopo, pringgitan, langgar, dan tembok keliling.

b. Ketib Tengah. Rumah Ketib Tengah bentuknya lebih permanen. Pada bagian depan telah mengalami penambahan yaitu untuk ruang tamu. Unsur-unsur 
bangunannya terdiri atas dalem, gandok, dan gadri (?), serta serta tanpa dilengkapi dengan pendopo, pringgitan, langgar, dan tembok keliling.

c. Ketib Amin (Tibamin). Rumah Ketib Amin pada bagian depan telah mengalami penambahan yaitu berupa teras dengan bahan semi permanen. Unsur-unsur bangunannya terdiri atas dalem, gandok, gadri (?), dan terdapat langgar yang sekarang dinamakan Langgar KHA. Dahlan. Rumah tersebut tidak dilengkapi dengan pendopo, pringgitan, dan tembok keliling.

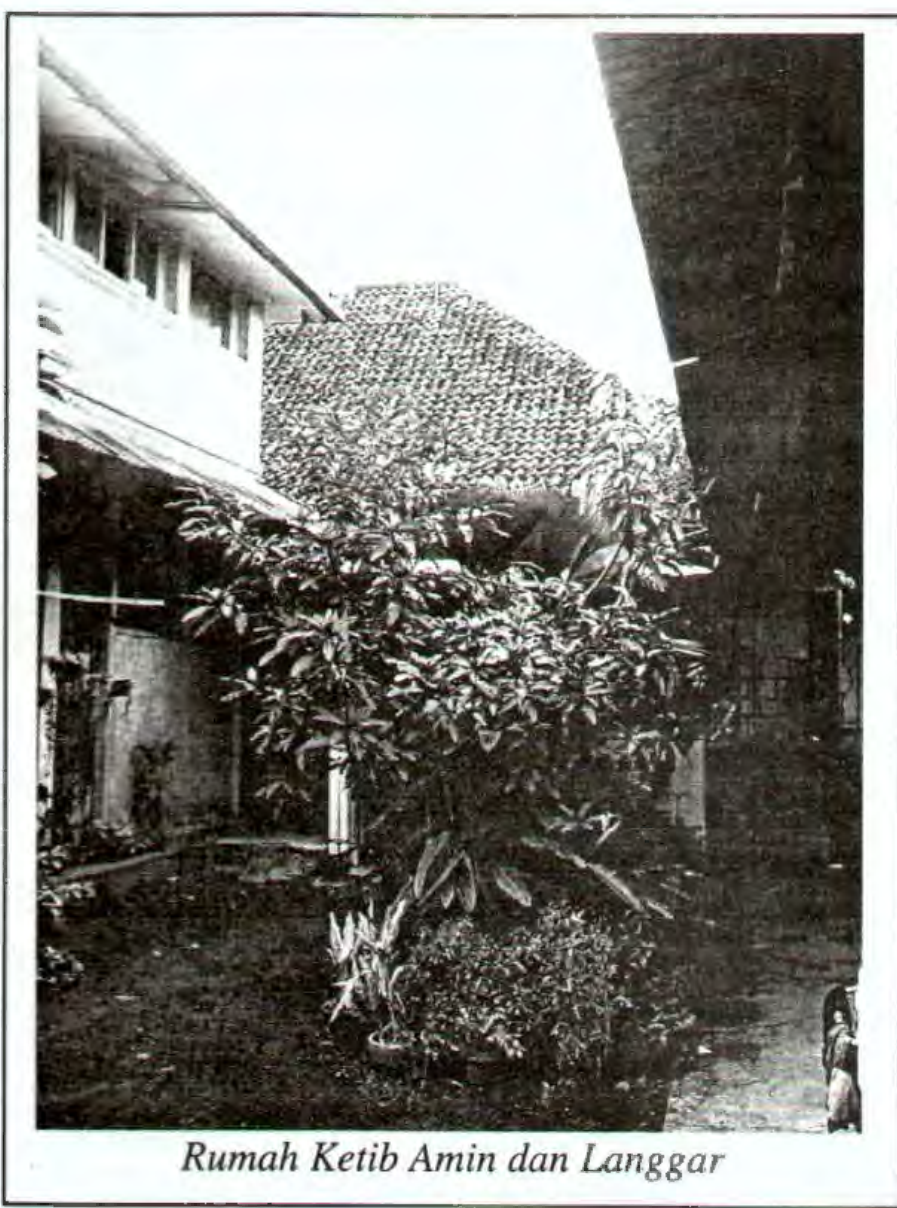

d. Ketib Wetan (Tibetan).

Unsur-unsur bangunannya terdiri atas pendopo, pringgitan, dalem, gandok, gadri (?), dan langgar, tanpa adanya tembok keliling. Rumah tersebut sekarang telah mengalami banyak perubahan, baik penambahan maupun pengurangan. Bagian depan yang dahulu terdapat pendopo, sekarang telah dijual kepada orang lain dan telah dibuat bangunan baru. Sementara pintu utama untuk masuk ke dalem dari arah pringgitan telah ditutup dengan tembok. Hal ini dilakukan mengingat masing-masing bagian telah dikuasai oleh anak cucu dari keturunan Ketib Wetan. Nomor rumah seperti tersebut di atas merupakan nomor rumah pada bagian dalem.

e. Ketib Lor (Tibelor). Unsur-unsur bangunannya terdiri atas dalem, gandok, dan gadri, serta serta tanpa adanya pendopo, pringgitan, langgar, dan tembok keliling. Rumah tersebut relatif masih asli, tetapi ada sedikit penambahan bangunan di bagian barat yang semula berupa halaman. Dengan demikian bangunan ini kurang jelas terlihat dari arah barat karena terhalang bangunan baru.

f. Ketib Sememi. Unsur-unsur bangunannya terdiri atas pendopo, pringgitan, dalem, gandok, dan gadri (?), tanpa dilengkapi dengan langgar (?) dan tembok keliling. Rumah tersebut sekarang telah mengalami banyak perubahan, baik 
penambahan maupun pengurangan. Di bagian depan dahulu terdapat pendopo, sekarang telah dijual kepada orang lain dan telah dibuat bangunan baru untuk dua keluarga yang berbeda. Sementara di atas pintu utama untuk masuk ke dalem dari arah pringgitan telah ditinggikan dengan tembok, sehingga bagian atap dalem hampir tidak kelihatan dari arah depan. Sedangkan bagian gandok tengen telah dibuat bangunan baru.

g. Ketib Cendono. Unsur-unsur bangunannya terdiri atas dalem, gandok, gadri (?), langgar, dan tembok keliling, tanpa dilengkapi dengan pendopo dan pringgitan. Bagian depan rumah merupakan halaman luas yang sekaligus merupakan halaman langgar, yaitu Langgar Arrosyad.

h. Ketib Imam (Tibimam). Rumah Ketib Anom unsurunsur bangunannya terdiri

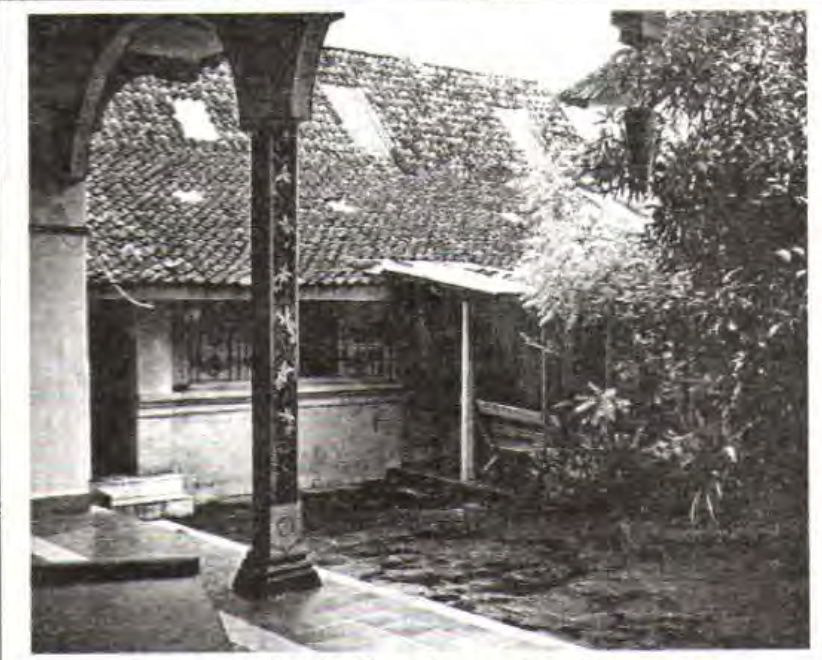

Rumah Ketib Cendono dan Langgar atas dalem, gandok, dan gadri (?), serta serta tanpa dilengkapi dengan pendopo, pringgitan, langgar, dan tembok keliling. Bagian depan rumah merupakan halaman yang cukup luas dan langsung menghadap ke jalan besar yaitu Jalan Kauman. Rumah tersebut sekarang telah mengalami banyak perubahan, terutama penambahan di beberapa bagian. Perubahan tersebut adalah penggantian genteng pada bagian dalem sekaligus penambahan pintu baru pada sisi timur, serta adanya bangunan baru di bagian depan yang dilengkapi pagar besi.

i. Ketib Kulon. Unsurunsur bangunannya terdiri atas pendopo, pringgitan, dalem, gandok, gadri (?), dan langgar, tanpa dilengkapi dengan tembok keliling. Di bagian depan (sebelah barat pendopo) terdapat langgar, terkenal dengan nama Langgar Duwur. Dinamakan Langgar Duwur karena bangunannya bertingkat,

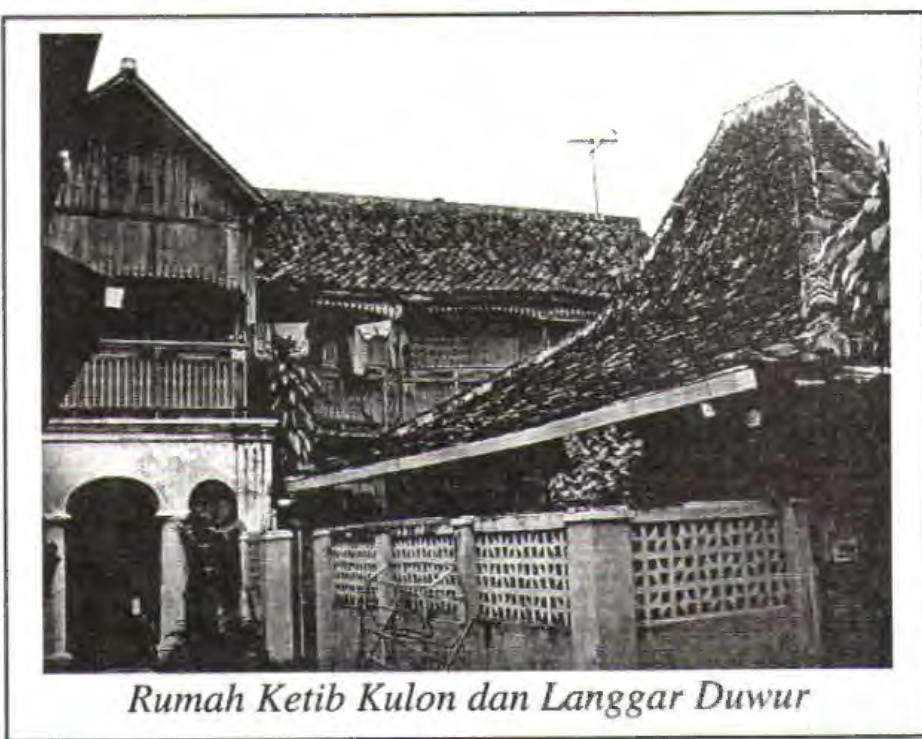


yaitu bagian atas berfungsi sebagai langgar dan bagian bawah sebagian untuk tempat tinggal dan sebagaian lagi untuk jalan rukun. Kira-kira pada tahun 1957 bangunan pendopo pada keempat sisinya telah ditutup dengan bata.

j. Ketib Arum (Tibarum) dan lihat Ketib Anom. Rumab Ketib Anom bentuknya sangat sederhana. Unsur-unsur bangunannya terdiri atas dalem, gandok, dan gadri (?), serta serta tanpa adanya pendopo, pringgitan, langgar, dan tembok keliling. Ketib Anom dan Ketib Arum menempati rumah yang sama, keduanya masih saudara. Salah seorang

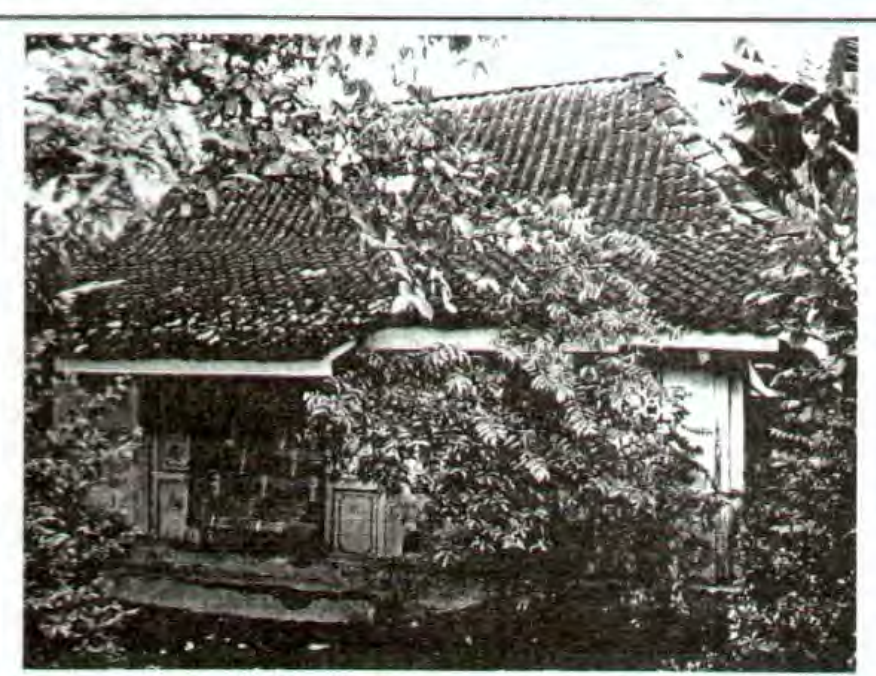

Rumah Ketib Arum dan Ketib Anom

Ketib Arum pernah dicalonkan sebagai pengganti Penghulu sebelumnya, sehingga mendapat nama Ketib Anom.

k. Ketib Miri. Unsur-unsur bangunannya terdiri atas pendopo (?), pringgitan (?), dalem, gandok, dan gadri (?), serta serta tanpa adanya langgar dan tembok keliling. Rumah tersebut dulunya sangat rendah kemudian oleh ahli warisnya ditinggikan kurang lebih 1 meter dengan cara menyambung beberapa tiang penyangga atap bangunan. Bagian pendopo telah dibongkar dan diganti dengan bangunan baru yang berfungsi sebagai kamar tidur dan ruang tamu.

3. Bangunan rumah Juragan Batik. Di Kauman terdapat beberapa rumah juragan batik atau rumah orang "kaya". Orang-orang ini bentuk rumahnya hampir sama dengan rumah-rumah Penghulu dan Ketib, yang membedakan adalah kelengkapannya, yaitu tidak dilengkapi dengan pendopo dan tembok keliling. Orang-orang "kaya" yang ada di Kauman pada umumnya mempunyai usaha yang sama yaitu sebagai juragan batik, salah satunya diberi nama Batik Handel. Hal ini sesuai dengan nama "sang juragan" yaitu $\mathrm{H}$. Moeh. Batikhandel (seperti yang tertera dalam prasasti). Di Kauman terdapat beberapa juragan batik yang tempat tinggalnya menyebar di seluruh Kauman. Dari beberapa juragan tersebut yang akan diuraikan terbatas hanya berjumlah 4 buah saja, mengingat bangunan rumah juragan batik yang lain sudah banyak mengalami perubahan, baik pengurangan (sebagian dijual pada orang lain) maupun penambahan. 
a. Rumah milik H.M. NARDJOE

BATIKHANDEL. Melihat namanya jelaslah bahwa usaha batiknya diberi nama Batik Handel. Bangunan ini bertingkat dua, tidak dilengkapi dengan pendopo, pringgitan,dan tembok keliling.

b. Rumah milik H. MOEH BATIKHANDEL. Melihat namanya jelaslah bahwa

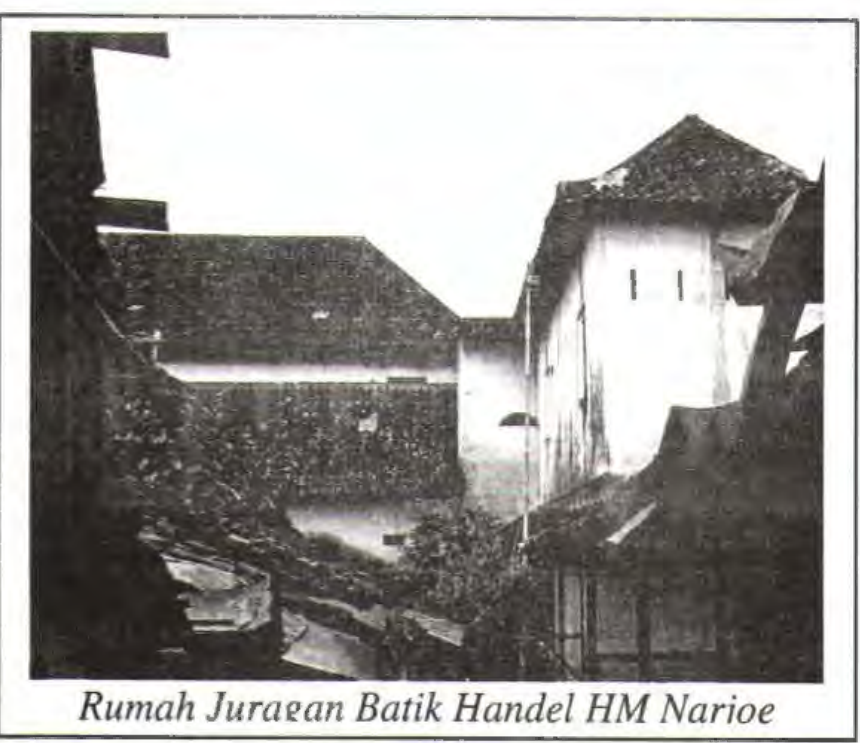
usaha batiknya juga diberi nama batik Handel dan H. MOEH merupakan kakak dari H.M. NARDJOE. Bangunan ini tidak bertingkat, tidak dilengkapi dengan pendopo, pringgitan, langgar, dan tembok keliling.

c. Rumah milik H. BADJURI HANIK. Bangunan ini bertingkat dua, tidak dilengkapi dengan pendopo, pringgitan, langgar, dan tembok keliling. Rumah tersebut sekarang sebagian telah dijual ke orang lain, yang tersisa tinggal bagian tengah.

d. Rumah milik H. IRSYAD. Bangunan ini bertingkat dua, tidak dilengkapi dengan

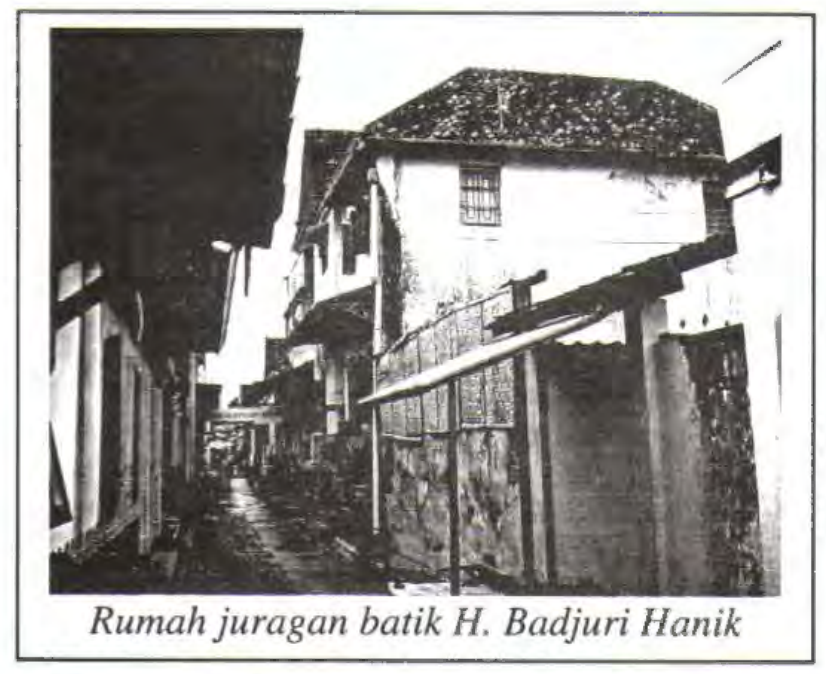
pendopo, pringgitan, langgar (?), dan tembok keliling. Bangunan ini sebagian telah dibagi waris yaitu untuk asrama putri. 


\begin{tabular}{|c|c|c|c|c|c|c|c|c|}
\hline \multirow{2}{*}{ No. } & \multirow{2}{*}{$\begin{array}{l}\text { Pemilik } \\
\text { Bangunan }\end{array}$} & \multicolumn{7}{|c|}{ Unsur Bangunan } \\
\hline & & P 1 & P 2 & D & G 1 & G 2 & Lg & Tk \\
\hline 1. & Penghulu & V & V & V & $\mathrm{V}$ & $\mathrm{V}$ & $\mathrm{V}$ & V \\
\hline 2. & Ketib Anom & $?$ & $?$ & V & $\mathrm{V}$ & $?$ & $\mathrm{X}$ & $\mathrm{X}$ \\
\hline 3. & Ketib Tengah & $\mathrm{X}$ & $\mathrm{X}$ & $\mathrm{V}$ & $\mathrm{V}$ & $?$ & $\mathrm{X}$ & $\mathrm{X}$ \\
\hline 4. & Ketib Amin & $X$ & $\mathrm{X}$ & $\mathrm{V}$ & V & $?$ & $\mathrm{~V}$ & $\mathrm{X}$ \\
\hline 5. & Ketib Wetan & $\mathrm{V}$ & $\mathrm{V}$ & $\mathrm{V}$ & $\mathrm{V}$ & $?$ & V & $\mathrm{X}$ \\
\hline 6. & Ketib Lor & $\mathrm{X}$ & $\mathrm{X}$ & V & V & V & $X$ & $X$ \\
\hline 7. & Ketib Sememi & V & V & $\mathrm{V}$ & $\mathrm{V}$ & $?$ & $?$ & $\mathrm{X}$ \\
\hline 8. & Ketib Cendono & $\mathrm{X}$ & $\mathrm{X}$ & V & V & $?$ & V & V \\
\hline 9. & Ketib Imam & $\mathrm{X}$ & $\mathrm{X}$ & $\mathrm{V}$ & V & $?$ & $\mathrm{X}$ & $\mathrm{X}$ \\
\hline 10. & Ketib Kulon & V & $\mathrm{V}$ & $\mathrm{V}$ & V & $\mathrm{V}$ & $\mathrm{V}$ & $\mathrm{X}$ \\
\hline 11. & Ketib Arum & $\mathrm{X}$ & $\mathrm{X}$ & $\mathrm{V}$ & $\mathrm{V}$ & $?$ & $\mathrm{X}$ & $\mathrm{X}$ \\
\hline 12. & Ketib Miri & $?$ & $?$ & $\mathrm{~V}$ & $\mathrm{~V}$ & $?$ & $\mathrm{X}$ & $\mathrm{X}$ \\
\hline 13. & H.M. Nardjoe Batikhandel & $\mathrm{X}$ & $\mathrm{X}$ & V & V & $\mathrm{V}$ & $\mathrm{X}$ & $\mathrm{X}$ \\
\hline 14. & H. Moeh Batikhandel & $\mathrm{X}$ & $\mathrm{X}$ & V & V & V & $\mathrm{X}$ & $\mathrm{X}$ \\
\hline 15. & H. Badjuri Hanik & $\mathrm{X}$ & $\mathrm{X}$ & $\mathrm{V}$ & $\mathrm{V}$ & $\mathrm{V}$ & $\mathrm{X}$ & $\mathrm{X}$ \\
\hline 16. & H. Irsyad & $\mathrm{X}$ & $\mathrm{X}$ & $\mathrm{V}$ & V & $\mathrm{V}$ & $?$ & $\mathrm{X}$ \\
\hline
\end{tabular}

\section{Keterangan:}

\begin{tabular}{|c|c|c|c|}
\hline $\begin{array}{l}\text { P } 1 \text { : Pendopo } \\
\text { P } 2 \text { : Pringgitan }\end{array}$ & $\begin{array}{l}\text { Lg : Langgar } \\
\text { Tk : Tembok Keliling }\end{array}$ & $\begin{array}{l}\text { G } 1: \text { : Gandok } \\
\text { G } 2: \text { Gadri }\end{array}$ & $\begin{array}{l}\mathbf{X}: \text { Tidak ada } \\
? \text { : Tidak jelas }\end{array}$ \\
\hline $\mathbf{n D}:$ Dalem V & & & \\
\hline
\end{tabular}

\section{Tinggalan Budaya Non Fisik}

Di Kampung Kauman selain terdapat tinggalan budaya bersifat fisik seperti tersebut di atas, juga terdapat hasil budaya yang masih berlangsung hingga sekarang ini. Hasil budaya tersebut berupa makanan khas Kauman yang dibuatnya secara turun temurun, walaupun pembuatnya tidak dari keluarga yang sama. Adapun jenis dan macamnya berfariasi. Dilihat dari waktu pembuatannya dapat dibedakan menjadi dua, yaitu makanan yang dibuat setiap saat (harian) dan ada pula makanan yang dibuat pada waktu-waktu tertentu (temporer). Makanan yang dibuat hanya pada waktu-waktu tertentu saja, misalnya pada bulan Romadhon - yang saat ini dikenal dengan "pasar tiban". Selain itu terdapat upacara-upacara keagamaan. Kegiatan ini erat kaitannya dengan keberadaan kraton dan masjid. Upacara-upacara tersebut antara lain Grebeg Besar, Grebeg Sawal, dan Sekaten yang berlangsung pada bulan Maulud pada setiap tahunnya. 
A nalisis Potensi dan Masalah (SWOT)

Analisis SWOT bertujuan untuk mendapatkan suatu pemahaman tentang kemampuan objek (baik individu maupun kelompok). Dalam rangka pengembangan di bidang kepariwisataan, analisis SWOT dipergunakan untuk membuat kajian pengembangan suatu sektor, wilayah, ataupun ODTW, dan akan menghasilkan beberapa skenario pengembangan. Skenario ini didapatkan dengan mengembangkan atau meningkatkan potensi dan meraih peluang setinggi-tingginya. Di samping itu pengembangan dilaksanakan untuk mengurangi kelemahan dan menghilangkan tantangan. Dalam analisis SWOT terdapat dua faktor utama yaitu faktor internal dan eksternal. Faktor internal akan menghasilkan kekuatan (strength) dan kelemahan (weaknesses). Sedangkan faktor eksternal akan menghasilkan peluang (opportunities) dan hambatan (threats) (Sasongko, 2003: 6 - 7).

\section{a. Strength (kekuatan)}

Kampung Kauman terletak di sebelah barat Alun-alun Utara Yogyakarta, di mana di kampung ini terdapat Masjid Besar, sering juga disebut dengan Masjid Agung atau Masjid Jami'. Dengan melihat nama masjid tentunya masjid ini dan alun-alunnya terletak di pusat kota. Seperti halnya di Surakarta, Demak, Cirebon dll Alun-alun dan Masjid Agung merupakan salah satu ciri kota yang terletak di pusat kota. Dengan begitu kampung ini sangat mudah dijangkau dari berbagai arah penjuru kota. Keberadaan Kampung Kauman tidak dapat dilepaskan dengan Kraton Yogyakarta, selain karena adanya hubungan kesejarahan juga letaknya yang relatif dekat. Kraton Yogyakarta dan beberapa unsur pendukungnya sebagai komponen pembentuk sebuah kota, pada saat ini terus dijaga kelestariannya dan selanjutnya difungsikan sebagai objek wisata (selain kraton itu sendiri), yaitu Taman Sari (istana air), Museum Sono Budoyo, Museum Benteng Vredenburg (benteng Belanda untuk mengawasi aktivitas kraton), Pasar Beringharjo (pasar tradisional), dan Malioboro (pusat perbelanjaan). 


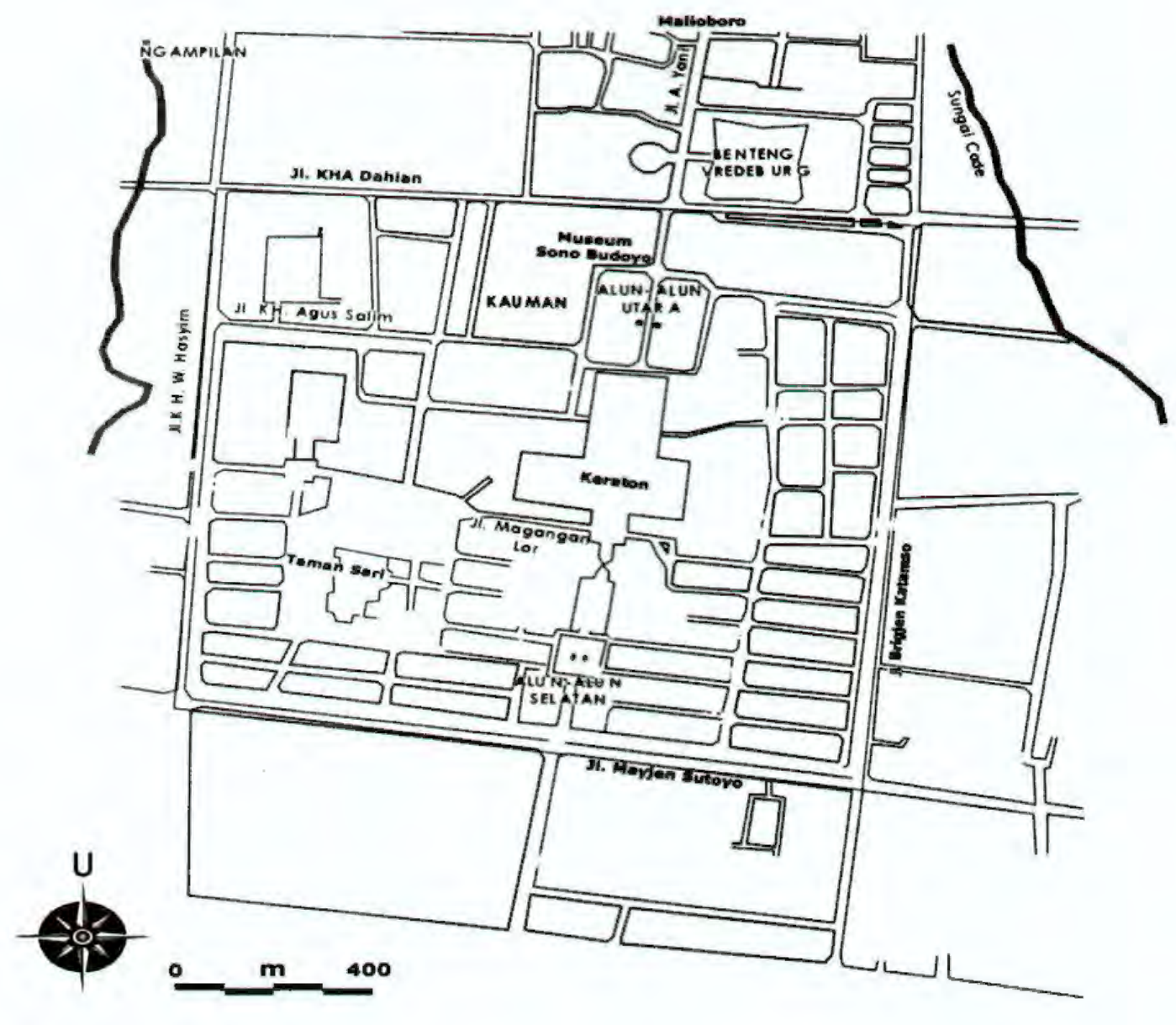

Peta keletakan Kauman di antara obyek wisata di sekitarnya Sumber Dinas Kebudayaan dan Pariwisata DIY dengan peubahan

\section{b. Weaknesses (Kelemahan)}

Kauman sebagai kampung tradisional tergolong kampung yang padat akan bangunan. Sementara jalan yang ada di dalamnya merupakan ciri jalan kampung yang disebut gang, sering disebut juga dengan istilah jalan rukun. Jalan-jalan tersebut terbentuk akibat terdapatnya bangunan-bangunan yang membentuk garis lurus sepanjang jalan (gang), sehingga terkesan seperti lorong (Mulyati, 1995: 69). Dengan keadaan seperti itu akses dari dan ke Kauman terkesan kurang lancar. Selain itu di Kauman ada aturan bahwa semua jenis kendaraan yang lewat tidak boleh dinaiki dan harus dituntun serta mesin harus dimatikan. Mengingat keadaan jalan yang sempit serta banyak anak-anak yang bermain di sekitarnya. Selain itu banyak bangunan-bangunan yang telah mengalami perubahan akibat masalah intern yang berkaitan dengan pembagian waris.

\section{c. Opportunities (Peluang)}

Bangunan-bangunan tradisional di Kauman dapat dijadikan sebagai model pelestarian dan pemanfaatan untuk wisata, khususnya wisata kota. Mengingat hingga saat ini 
belum banyak model wisata kota, utamanya kota-kota yang pernah memegang peranan penting dalam kaitannya dengan timbul dan berkembangnya suatu kerajaan, yaitu Kerajaan Mataram Islam.

\section{d. Threats (Hambatan)}

Sebetulnya model pelestarian dan pemanfaatan bangunan-bangunan tradisional untuk kegiatan kepariwisataan masih langka. Kelangkaan ini salah satunya disebabkan kalah saing dan gaungnya kurang luas dibandingkan dengan bentuk-bentuk wisata yang sudah ada dan dikenal masyarakat luas. Misalnya: dunia fantasi dan sea word (khusus untuk anak-anak - kenyataannya banyak orang tua yang juga tertarik menikmati) dll.

Berdasarkan uraian tentang analisis SWOT di atas dapat disusun suatu tabel sebagai skeario atau strategi pengembangan kepariwisataan, yaitu:

a. Startegi Pertama $(\mathrm{I}) \rightarrow(\mathrm{S} / \mathrm{O})$ maksudnya adalah memanfaatkan kekuatan $\mathrm{S}$ (Strength) secara maksimal untuk meraih peluang O (Opportumity).

b. Startegi Kedua (II) $\rightarrow$ (S/T) maksudnya adalah memanfaatkan kekuatan $S$ (Strength) secara maksimal untuk mengantisipasi dan menghadapi ancaman $\mathrm{T}$ (Threats).

c. Startegi Ketiga (III) $\rightarrow$ (W/O) maksudnya adalah meminimalkan kelemahan W (Weaknesses) untuk merailh peluang O (Opportunity).

d. Startegi Keempat (IV) $\rightarrow(\mathrm{W} / \mathrm{T})$ maksudnya adalah meminimalkan kelemahan W (Weaknesses) untuk menghindari secara lebih baik dari ancaman T (Threats).

\begin{tabular}{|c|c|c|}
\hline & Peluang (Opportunity) & Ancaman (Threats) \\
\hline Kekuatan (Strength) & Strategi I (S/O) & Strategi II (S/T) \\
\hline Kelemahan (Weaknesses) & Strategi III (W/O) & Strategi IV (W/T) \\
\hline
\end{tabular}

Strategi yang disusun tersebut sesungguhnya merupakan satu kesatuan yang diharapkan dapat mewujudkan visi melalui misi pengembangan kepariwisataan yang telah dirumuskan (Sasongko, 2003: 8 - 9).

Sementara itu bentuk analisis SWOT yang lain dapat dilakukan dalam bentuk seperti di bawah ini.

\begin{tabular}{|c|c|c|}
\hline & Strength (Kekuatan) & Weaknesses (Kelemahan) \\
\hline $\begin{array}{c}\text { Opportunities } \\
\text { (Peluang) }\end{array}$ & Ekspansi (pengembangan) & Konsolidasi Internal \\
\hline Threats (Hambatan) & Diversifikasi & Introspeksi \\
\hline
\end{tabular}

a. Apabila Strength (Kekuatan) bertemu dengan Opportunities (Peluang) yang terjadi adalah ekspansi (pengembangan), maka kepariwisataan tersebut memungkinkan untuk dapat dikembangkan dan dimasyarakatkan. 
b. Apabila Weaknesses (Kelemahan) bertemu dengan Opportunities (Peluang) yang terjadi adalah konsolidasi internal. Salah satu kegiatan yang dilakukan berupa mempersiapkan sarana dan prasarana yang memadai.

c. Apabila Strength (Kekuatan) bertemu dengan Threats (Hambatan) yang terjadi adalah diversifikasi, maka perlu adanya penguatan program-program kepariwisataan.

d. Apabila Weaknesses (Kelemahan) bertemu dengan Threats (Hambatan) yang terjadi adalah introspeksi. Salah satu kegiatan yang dilakukan konsolidasi organisasi dengan cara peninjauan struktur, mekanisme, deskripsi kerja dan kinerja (Hatmoko, 2003).

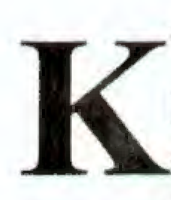
onsep dan Dasar Pemikiran Perencanaan

Pembangunan pariwisata pada hakekatnya merupakan upaya untuk mengembangkan dan memanfaatkan, serta mendayagunakan berbagai potensi kepariwisataan nasional yang berupa objek dan daya tarik wisata (baca: ODTW) yang terwujud antara lain dalam bentuk kekayaan alam yang indah, beragamnya flora dan fauna, berbagai macam tradisi dan seni budaya serta peninggalan sejarah dan purbakala (Anonim, 1993: 69-70).

Perkembangan pariwisata di Indonesia dari tahun ke tahun tampak mengalami peningkatan yang pesat sehingga secara signifikan mendorong perkembangan perekonomian nasional, terutama yang berlangsung sebelum terjadinya krisis moneter tahun 1997. Perkembangan ini sejalan dengan kebijaksanaan pemerintah untuk menjadikan sektor pariwisata sebagai salah satu alternatif sumber devisa bagi negara untuk pembangunan, baik pembangunan fisik maupun pembangunan manusia Indonesia seutuhnya. Peningkatan ini juga sebagai akibat adanya dampak atas peningkatan kesejahteraan hidup dan mobilitas masyarakat yang berasal dari negaranegara industri maju sehingga jumlah turis mancanegara yang berkunjung ke Indonesia semakin bertambah. Hal ini terbukti dengan jumlah arus wisatawan internasional (wisman) yang dari tahun ke tahun mengalami peningkatan (Dalimunthe, 2001:2-3).

Kepariwisataan dalam pengelolaannya dianggap sebagai sebuah industri yang menghasilkan devisa bagi negara. Pariwisata sebagai sebuah industri mempunyai keterkaitan yang erat dengan lingkungan, baik fisik maupun sosio-kultural. Oleh karena itu, tidak dapat dipungkiri bahwa adanya program pengembangan kawasan industri pariwisata tersebut jelas membawa dampak baik fisik maupun non fisik, positif maupun negatif. Sebab keberadaan suatu kegiatan pasti memiliki dampak positif sekaligus negatif terhadap kehidupan masyarakat di sekitarnya (Usman, 1996: 37). 
Untuk lebih memfokuskan industri kepariwisataan dapat melalui pendekatan dengan paradigma industri budaya (culture industry). Industri ini bertujuan untuk memaksimalkan potensi yang dimiliki oleh obyek peninggalan sejarah dan kepurbakalaan agar dapat memiliki nilai jual. Konsep industri kebudayaan dalam perencanaan dan pengembangan kepariwisataan tidak memperlakukan budaya tersebut sebagai komoditi (culture as a commodity). Industri yang dimaksud adalah suatu kegiatan yang di dalamnya meliputi perencanaan (planning) dan pembangunan (development), pengelolaan (management), pemasaran (marketing), investasi (investment), dan pelestarian (conservation). (Nuryanti, 2002: 6 - 7).

\section{Pengembangan Wisata Budaya Sebagai Alternatif}

Untuk lebih memperkaya bentuk-bentuk kepariwisataan yang sudah ada terutama dalam menaikkan sumber devisa bagi negara untuk pembangunan perlu dicari bentukbentuk kepariwisataan lain. Sejalan dengan hal tersebut perlu dikembangkan dan dikenalkan bentuk-bentuk wisata baru, selain bentuk kepariwisataan yang sudah ada dan telah dikenal oleh masyarakat luas. Sebagai alternatif perlu ditumbuhkembangkan dan diperkenalkan kepada khalayak adalah wisata budaya yang berkaitan dengan bangunan tradisional Jawa di suatu lokasi tertentu, khususnya bangunan tradisional di Kampung Kauman Yogyakarta.

\section{Kendala-kendala Yang Ada}

Bangunan-bangunan tradisional Jawa yang ada di Kampung Kauman telah berusia tua, hingga saat ini telah melewati beberapa generasi, rata-rata 4 hingga 5 generasi. Dengan demikian satu bangunan yang pada awalnya ditempati oleh satu keluarga, sekarang ini ditinggali oleh beberapa keluarga dari satu keturunan. Oleh karena anggota keluarganya bertambah banyak, sementara rumah tinggalnya tetap dan tidak bertambah luas. Hal ini mengakibatkan bangunan-bangunan tersebut terpaksa dibagi sesuai dengan ahli warisnya. Ada satu keluarga dapat bagian pendopo, ada yang mendapat jatah bagian "ndalem", bagian gadri, bagian gandok dll. Kenyataan yang ada dapat dilihat yaitu bangunan pendopo yang awalnya merupakan bangunan terbuka, sekarang ini menjadi bangunan tertutup (dengan konstruksi bata) - karena dijadikan sebuah rumah tinggal keluarga dengan beberapa kamar tidur.

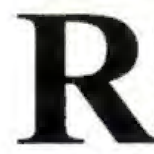

\section{ekomendasi Pengembangan}

Untuk melestarikan eksistensi bangunan-bangunan tradisional yang ada di - Kauman perlu diupayakan kegiatan-kegiatan yang secara langsung maupun tidak langsung ditujukan kepada bangunan-bangunan maupun "kegiatan-kegiatan" lain yang terdapat di sekitarnya. Kegiatan yang secara langsung ditujukan terhadap bangunan antara lain yang paling pokok adalah kesadaran para pemilik bangunan untuk tetap "nguri-uri" bangunan tersebut sebagai warisan leluhurnya. Selanjutnya yang berkaitan dengan bangunan tradisional yang terdapat di Kampung Kauman 
tersebut dapat digunakan untuk berbagai bentuk kegiatan kepariwisataan sesuai dengan fungsinya masing-masing bangunan, yaitu:

\section{Bangunan Milik Ketib}

Di Kauman terdapat 11 nama jenis ketib yang menempati 10 rumah yang berbeda, sebab ada dua ketib yang menempati rumah yang sama. Berdasarkan tabel di atas yang berkaitan dengan kelengkapan unsur-unsur bangunannya, dapat diketahui bahwa masing-masing bangunan ketib tidak sama. Perbedaan tersebut salah satunya disebabkan kemampuan (baca: kaya) yang tidak sama. Ada ketib yang tidak mampu tetapi ada juga ketib yang mampu (kaya). Oleh karena itu tidak semua bangunan milik ketib dapat dijadikan sebagai objek kepariwisataan. Selain itu disebabkan pula ada beberapa bangunan ketib yang telah banyak mengalami perubahan, sehingga kekunoannya hampir tidak terlihat.

Berkaitan dengan kepariwisataan, bangunan-bangunan tersebut di masa mendatang dapat dijadikan sebagai "semacam" art shop. Art shop tersebut khusus menyediakan dan menjual barang-barang atau cindera mata yang berkaitan dengan keberadaan Kampung Kauman (termasuk Masjid Besar) dan Kraton Yogyakarta. Cindera mata yang dimaksud dapat berupa "prototipe" jenis-jenis batik yang dahulu pernah dibuat di kampung ini, miniatur masjid, repro foto-foto kuno masjid dan bagian-bagiannya serta kraton, kaos dan gantungan kunci dengan gambar masjid maupun kraton, stiker dll. Selain itu, art shop tersebut dapat menyediakan pula makanan khas Kauman baik yang dibuat setiap hari maupun yang pembuatannya bersifat temporer (waktu-waktu tertentu).

Bentuk kepariwisataan seperti ini lebih ditujukan kepada wisatawan nusantara (wisnus), sebab jenis wisatawan ini merupakan potensi yang sangat besar. Mengingat wisatawan nusantara memiliki pertalian akar sejarah dan nilai tradisi yang lebih dari pada wisatawan mancanegara. Sumber kekuatan pembangunan pariwisata agar dapat berlanjut sangat tergantung antara lain oleh terciptanya rasa kebanggaan atas potensi tersebut oleh masyarakat itu sendiri (Nuryanti, 2002: 89).

2. Bangunan Milik Juragan Batik

Bangunan tradisional di Kauman yang dimiliki oleh para juragan batik jumlahnya banyak. Yang akan ditampilkan dalam tulisan ini hanya beberapa saja (4 buah bangunan) yang dimungkinkan dapat mewakilinya. Juragan batik di Kauman dapat dipisahkan menjadi dua berdasarkan pekerjaannya, yaitu: a). produsen sekaligus pedagang (penjual); b). produsen saja yang hasil pekerjaannya disetorkan kepada pedagang (penjual). Dalam tulisan ini keduanya tidak dipisahkan, karena yang dibahas berdasarkan objeknya yaitu bangunan rumah milik juragan batik. Pada umumnya rumah juragan batik bentuknya tingkat. 
Unsur-unsur bangunannya tidak berbeda dengan bangunan tradisional lainnya, meskipun ada beberapa bagian yang tidak ada.

Bangunan-bangunan tersebut dikemudian hari dapat dimanfaatkan tidak hanya sebagai tempat tinggal saja, melainkan untuk kepentingan-kepentingan lain yang dapat bermanfaat bagi banyak orang. Salah satunya bagi kepentingan kepariwisataan. Bentuk pemanfaatan untuk kepariwisataan diselaraskan dengan fungsi bangunan pada waktu itu, yaitu berkaitan dengan kegiatan "perbatikan", Kegiatan membatik di Kauman dapat dibedakan menjadi dua berdasarkan cara kerjanya, yaitu batik cap dan batik tulis. Bangunan-bangunan tradisional yang dikaitkan dengan kepariwisataan adalah dalam bentuk kegiatan membatik, khususnya batik tulis. Kepariwisataan dalam bentuk membatik bersifat aktif, maksudnya adalah menyertakan para wisatawan dalam proses pembuatan batik. Kegiatan kepariwisataan yang bersifat aktif dengan mengikutsertakan wisatawan sangat digemari terutama oleh wisatawan asing (wisman). Diawali dengan membuat pola di atas kain yang dilanjutkan dengan pemberian malam atau lilin di atas pola tersebut, pemberian warna hingga berakhirnya proses membatik.

\section{Bangunan Kawedanan Pengulon}

Bangunan ini statusnya masih menjadi hak milik Kraton Yogyakarta, oleh karena itu hingga saat ini masih difungsikan sebagai kantor yaitu Kawedanan Pengulon terbukti masih dipakai "caos" abdi dalem. Berkaitan dengan dua jenis bangunan tradisional seperti yang telah diuraikan di atas (bangunan milik ketib dan juragan batik) yang dikaitkan dengan jenis atau model kepariwisataan, maka bangunan ini (Kawedanan Pengulon) dapat melengkapinya yaitu difungsikan sebagai kantor pusat informasi. Kantor ini akan dapat memberikan informasi tentang bangunan milik ketib maupun milik juragan batik serta segala sesuatu yang pernah terjadi di kampung ini, baik yang berkaitan dengan sejarah, arsitektur bangunan-bangunan yang ada, maupun tinggalan budaya (non fisik) yang masih berlangsung hingga saat ini.

Sistem dan bentuk pengelolaan kepariwisataan seperti itu dapat dilihat di Kraton Yogyakarta. Kraton Yogyakarta dan lingkungannya sebagai obyek wisata merupakan hak milik pihak Kasultanan Ngayogyakarta Hadiningrat. Sementara itu dalam pengelolaan kepariwisataannya ditangani langsung oleh Pemerintah Daerah Yogyakarta. Pemerintah Daerah Yogyakarta dalam mengelola kepariwisataan Kraton Yogyakarta menempati kantornya di bangunan sisi barat, yaitu di bangsal pacaosan prajurit yang terletak pada halaman Sri Manganti (Dwidjasaraja, 1935: 6). Demikian pula dengan bangunan Kawedanan Pengulon tentunya dapat dijadikan sebagai kantor sekaligus sebagai pusat informasi. Sedangkan sebagai pengelola sebaiknya diseralıkan pada pihak swasta, sementara 
pihak pemerintah lebih berkonsentrasi di bidang pengaturan, perijinan, dan kontrol (pengawasan) (Nuryanti, 2002: 8).

Berdasarkan atas uraian-uraian dari ketiga jenis bangunan tradisional berdasarkan kepemilikannya tersebut dapat direkomendasikan sebagai berikut:

1. Bangunan Kawedanan Pengulon direkomendasikan untuk dapat dijadikan kantor sekaligus sebagi pusat informasi.

2. Bangunan Ketib direkomendasikan untuk dapat dijadikan art shop yang menyediakan cindera mata dan makanan khas Kauman dengan pangsa pasar utamanya wisatawan nusantara/domestik/lokal.

3. Bangunan Juragan Batik direkomendasikan untuk dapat dijadikan sebagai obyek wisata batik tulis yang bersifat aktif. Maksudnya bahwa wisatawan yang datang diikutkan secara aktif dalam proses pembuatan batik tulis sejak mulai membuat pola pada kain hingga selesai dengan pangsa pasarnya adalah wisatawan asing/wisman.

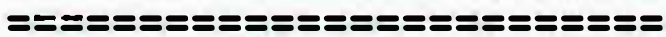

KEPUSTAKAAN

Anonim. 1993. Garis-garis Besar Haluan Negara 1993 - 1998. Jakarta: Sinar Grafika.

Chawari, Muhammad. 1989. Pasang Surut Perkembangan Pembangunan Masjid Besar Kauman Yogyakarta: Studi Berdasarkan Sumber Prasasti. Yogyakarta: Skripsi Sarjana pada Jurusan Arkeologi, Fakultas Sastra, Universitas Gadjah Mada.

Chawari, M. (1999). Arsitektur Bangunan Rumah Tradisional Jawa: Keberadaan Bangunan Tradisional Jawa di Kampung Kauman, Yogyakarta. Berkala Arkeologi, 19(1), 128-137. https://doi.org/10.30883/jba.v19i1.798

Dalimunthe, Gaga Baktha. 2001. Ketegangan Kepentingan Pemerintah, Pengusalaa, dan Masyarakat Lokal Dalam Pembangunan Pariwisata: Studi Kasus Tentang Konflik Sosial Penertiban Asongan di Kawasan Taman IVisata Candi Borobudur, Jawa Tengah. Jogjakarta: Skripsi Jurusan Sosiologi, Fakultas Ilmu Sosial dan Ilmu Politik, UGM.

Berkala Arkeologi Th. XX/V(I) 
Darban, Ahmad Adaby. 2000. Sejarah Kauman, Menguak Identitas Kampung Muhammadiyah. Yogyakarta: Penerbit Trawang.

Dwidjasaraja, A.S. 1935. Ngajogjakarta Hadiningrat Jilid I. Yogyakarta: Percetakan Mardi-Moelja.

Hatmoko, Adi Utomo,. 2003. Analisis SWOT Program Studi Pengembangan Wilayah. Yogyakarta: Makalah dalam Diklat Fungsional Pariwisata, Pusdiklat-BP Budpar.

Mulyati, Ahda. 1995. Pola Spasial Permukiman Di Kampung Kauman Yogyakarta. Yogyakarta: Tesis pada Program Studi Teknik Arsitektur, Jurusan Ilmu-ilmu Teknik, Program Pasca Sarjana Universitas Gadjah Mada.

Nuryanti, Wiendu. 2002. Pengembangan Benda Cagar Budaya Dalam Konteks "Global - Lokal". Yogyakarta.

Prijotomo, Josef. 1992. Ideas and Forms of Javanese Archetecture. Yogyakarta: Gadjah Mada University Press, Cetakan Ketiga.

Sasongko, Sotya. 2003. Metode Jaring Data Dan Analisis ODTW. Yogyakarta: Makalah dalam Diklat Fungsional Pariwisata, Pusdiklat-BP Budpar.

Usman, Sunyoto. 1996. Sosiologi Lingkungan. Yogyakarta: Fisipol UGM. 